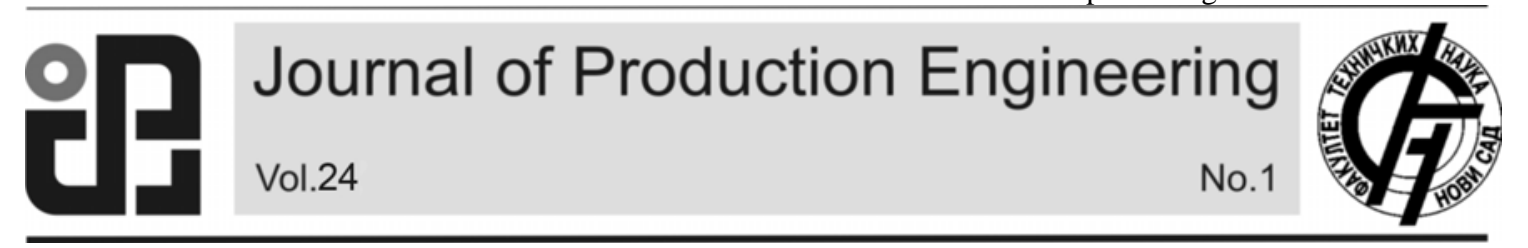

JPE (2021) Vol.24 (1)

Tamás, $\mathbf{P}$.

Original Scientific Paper

\title{
APPLICATION POSSIBILITIES OF DYNAMIC VALUE STREAM MAPPING IN PRODUCTION LOGISTICS
}

Received: 09 March 2021 / Accepted: 23 June 2021

Abstract: An increase in the number of product types required by customers results in an increase in the complexity of logistics systems. This finding is particularly characteristic of production logistics systems, where the use of flexible production systems is becoming increasingly important. One of the defining tools for the development of these processes is the value process mapping method, a static version of which suitable for the simultaneous examination of a product family has become widespread in corporate practice. The paper presents the method of dynamic value stream mapping, which is also suitable for the examination of complex logistics systems, exploring its steps and the possibilities of its application in production logistics. An example prepared using the VSM module of the Plant Simulation framework is also presented to illustrate the application of the method.

Key words: VSM, production logistics, process improvement.

Mogućnosti primene dinamičkog mapiranja tokova vrednosti u proizvodnoj logistici. Povećanje broja vrsta proizvoda koje zahtevaju kupci rezultira povećanjem složenosti logističkih sistema. Ovo otkriće je posebno karakteristično za proizvodne logističke sisteme, gde upotreba fleksibilnih proizvodnih sistema postaje sve važnija. Jedan od alata za definisanje razvoja ovih procesa je metoda mapiranja procesa vrednosti, čija je statična verzija pogodna za istovremeno ispitivanje porodice proizvoda postao je široko rasprostranjen u korporativnoj praksi. $U$ radu je predstavljena metoda dinamičkog mapiranja tokova vrednosti, koja je takođe pogodna za ispitivanje složenih logističkih sistema, istražujući njegove korake i mogućnosti njegove primene u proizvodnoj logistici. Primer koji je pripremljen korišćenjem VSM modula okvira za simulaciju biljaka takođe je predstavljen radi ilustracije primene metode.

Ključne reči: VSM, proizvodna logistika, unapređenje procesa.

\section{INTRODUCTION}

The development of logistics processes has become a key factor for all production and logistics service companies. Companies that are unable to use their corporate culture to use process methods to improve their processes will soon lose their competitiveness [1]. One of the most important tools in lean philosophy is the value process mapping method, which was developed using Toyota's material and information flow diagram. The method was first published by Mike Rother \& John Shook in 1999 in "Learning to See" [2]. The basic goal of the method is to eliminate the wastes and thus to improve material and information flow processes.

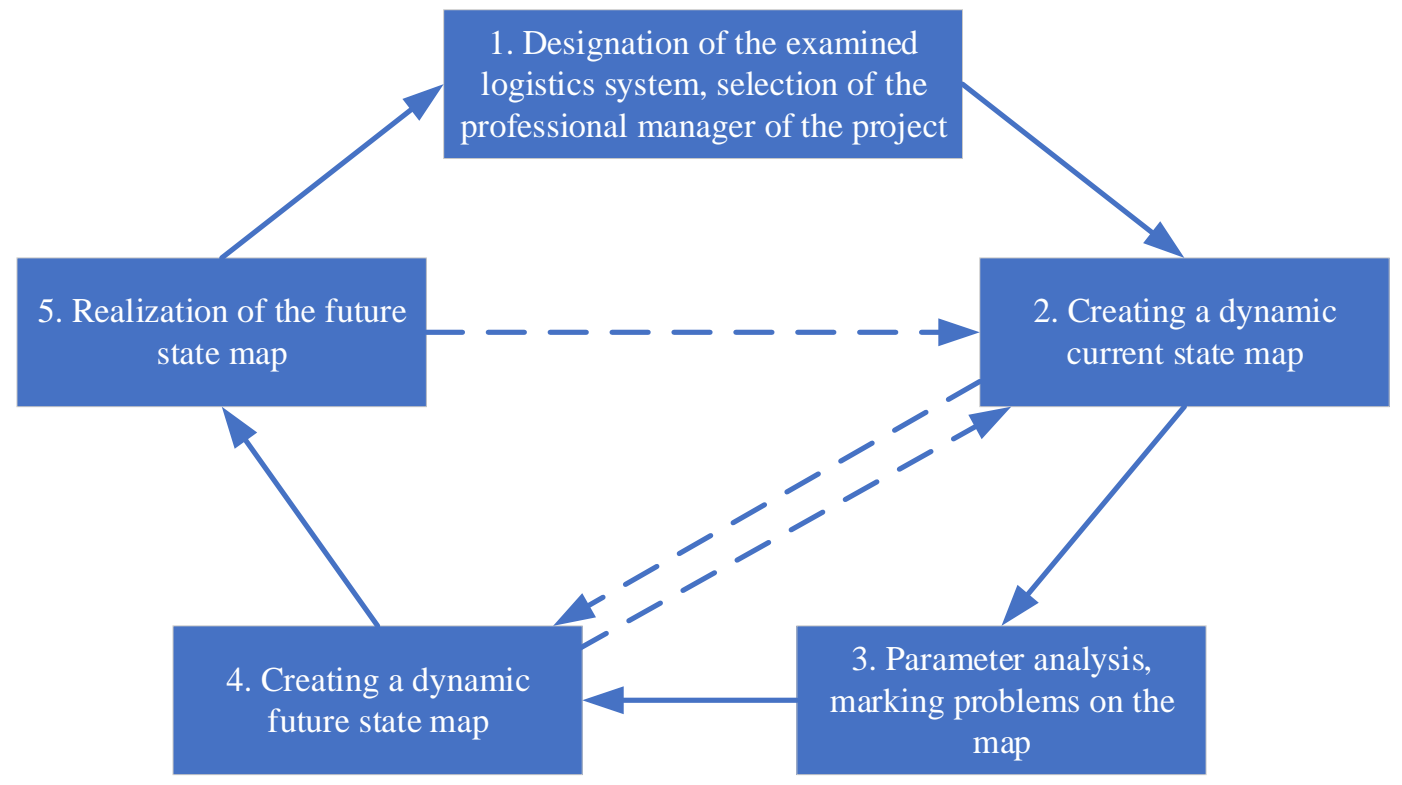

Fig. 1. Steps of the dynamic value stream mapping method [edited by me] 
In addition to this objective, there are several advantageous features of the method, which are the following [2, 3]:

- makes logistics processes transparent,

- supports the understanding of the examined processes,

- helps to identify losses,

- helps to define the stages of development.

Two types of value process mapping methods can be distinguished. The method of static value stream mapping [2, 3], in which only the processes of one product family can be examined at a time, and the method of dynamic value stream mapping [3, 4], where we have the possibility to examine the processes of several product families simultaneously with the possibility of dynamic transformation of created value stream maps. In the case of the static value stream mapping method it is enough to use only one paper and a pencil, but in the case of the dynamic value process mapping method it is necessary to use the simulation modeling. In the following, the method of dynamic value stream process mapping and its application in the production area are presented.

\section{DYNAMIC VALUE STREAM MAPPING METHOD}

The implementation steps of the dynamic value stream mapping method are illustrated in Figure 1, which are as follows [3, 5]:

1. Designation of the examined logistics system, selection of the professional manager of the project: In this step, in accordance with the objectives of the examination, the examined system must be designated, and then the product families occurring and to be examined must be defined. Next, a binding matrix must be formed, which contains which value families to which the examined product families belong. In addition, the professional responsible for the development project should be selected from among the value stream managers or, if necessary, from a higher management level.

2. Creating a dynamic current state map: Creating a present state map requires special knowledge, as a simulation application must be created. Consequently, a person suitable for performing simulation studies (depending on the size of the task, several people) should be selected who is familiar with the processes of the designated system and develops the study model based on the instructions of the project professional.

3. Parameter analysis, marking problems on the map: With the help of the dynamic current state map it is possible to examine the effects of different input data on operational characteristics (e. g. effect of reduction of chanegover time on inter-operational stock, effect of cycle time change on performance, etc.). A systematic examination requested by the professional manager of the project - in consultation with the relevant value process managers if necessary - can be used to define the problems to be solved of the examined subsystem, which will be marked.

4. Creating a dynamic future state map: Additional simulation studies may be required to solve the identified problems. After solving the problems, a dynamic future state map containing the expected future state must be created.

5. Realization of the future state map: Similar to the method of static value stream mapping, in this method the value stream loops and the action list belonging to the loops must be defined. This is followed by the preparation of the annual value stream plan and its implementation within a controlled framework. Unlike the static value process mapping method, the developments defined in connection with the subsystem processes are coordinated and controlled by the professional manager of the project with the participation of the value stream managers.

The relationship between the steps of the method is not always one-way, there may be feedback, e.g. if, when creating a future status map, we need information that is not included in the current state map. In this case, the current state map must be modified, or if the future state map is implemented, step 1 or 2 follows again, thus repeating the process cyclically. A comparison of the static and dynamic value stream mapping method based on different aspects is presented in Table 1.

\begin{tabular}{|c|c|c|}
\hline Aspects & $\begin{array}{c}\text { Static value } \\
\text { stream } \\
\text { mapping }\end{array}$ & $\begin{array}{c}\text { Dynamic } \\
\text { value stream } \\
\text { mapping }\end{array}$ \\
\hline $\begin{array}{c}\text { Subject of } \\
\text { investigation } \\
\text { logistics } \\
\text { process of a } \\
\text { selected } \\
\text { product family }\end{array}$ & $\begin{array}{c}\text { logistic } \\
\text { processes of a } \\
\text { defined } \\
\text { subsystem }\end{array}$ \\
\hline $\begin{array}{c}\text { Complexity of } \\
\text { the investigated } \\
\text { process(es) }\end{array}$ & low & high \\
\hline $\begin{array}{c}\text { Tools used to } \\
\text { create value } \\
\text { stream maps }\end{array}$ & paper, pencil & simulation \\
framework \\
\hline $\begin{array}{c}\text { Carrying out } \\
\text { impact } \\
\text { assessments }\end{array}$ & $\begin{array}{c}\text { not or only to a } \\
\text { limited extent } \\
\text { possible }\end{array}$ & possible \\
\hline $\begin{array}{c}\text { Consideration of } \\
\text { stochasticity in } \\
\text { studies }\end{array}$ & $\begin{array}{c}\text { not or only to a } \\
\text { limited extent } \\
\text { possible }\end{array}$ & possible \\
\hline
\end{tabular}

Table 1. Comparison of the static and dynamic value stream mapping method based on different aspects [Edited by me]

In my opinion, as the complexity of the processes increases, the role of the static value stream mapping method will not decrease significantly, as the development of processes by product family will continue to be important.

\section{APPLICATION POSSIBILITIES OF DYNAMIC VALUE STREAM MAPPING IN PRODUCTION LOGISTICS}

There are several ways to implement the dynamic value stream mapping method, i. e. by creating a new application or using objects from simulation frameworks [5]. In terms of examination efficiency, the 
use of simulation frameworks (e. g., Arena, Simul8, Plant Simulation, etc.) is clearly preferable. In this respect, the Plant Simulation framework also has a separate VSM module, which represents a significant simplification in the application of dynamic value stream mapping [4].

With this type of value stream mapping method, we can support more efficient transformation in three areas compared to the static value stream mapping method, which are:

- Determination of operational characteristics: The results of the effects associated with the modification of the selected parameters can be queried, which can contribute to a more efficient implementation of steps 2-4 of the method. These can be e. g. the effect of changing the changeover time on interoperatinal stocks; the effect of changing the batch size on the lead time, the effect of changing the production plan on the quantity of finished products, etc.

- Selection of an optimal operating alternative: Once the problems have been identified, in most cases alternatives can be developed for the future state. With dynamic value process mapping, these alternatives can be easily compared while modifying parameters. Mentioned as an example, a different storage systems can be designed for the future, however, each type has different space requirements, inventory levels, and lead times. From these alternatives, the ideal can be selected using a decision making method if necessary.

- Optimization of operational characteristics: When preparing the future state map, it may be necessary to determine the parameters optimally, with the help of which an increase in efficiency can be achieved after implementation. Such may be, e. g. determining the number of kanban cards, preparing an optimal production plan, etc. [6].

It can be said that in order to exploit these potentials in the field of production, there is a growing need to apply the method of dynamic value stream mapping, the practical application of which is presented through an example.

\section{APPLYING A DYNAMIC VALUE STREAM MAPPING METHOD TO EXAMINE INTER- OPERATIONAL INVENTORIES}

This chapter presents an example of one of the possibilities of the dynamic value stream mapping method, i. e. to examine the effects of parameter changes. The VSM module of the Plant Simulation framework was applied to create the example [6]. This module contains the objects defined by the VSM method and all their configuration options. The system shown in Figure 2 includes two processes as well as two storage systems, namely a supermarket and an unregulated stock store. After setting the input parameters, any parameters of the system objects can be queried both at run time (see Figure 3 ) and at the end of run time (see Figure 4). Compared to the static value stream mapping method, this option contributes significantly to reducing design uncertainty, minimizing investment costs, and efficient process development.

Figure 3 illustrates that during its run time, the inventory level of the supermarket fluctuated between 100 and 500 products, and the stock level of unregulated stock storage fluctuated between 10 and 150 products.

Figure 4 shows the most important characteristics of the process object, i.e. the number of incoming and outgoing products and the different utilization data.

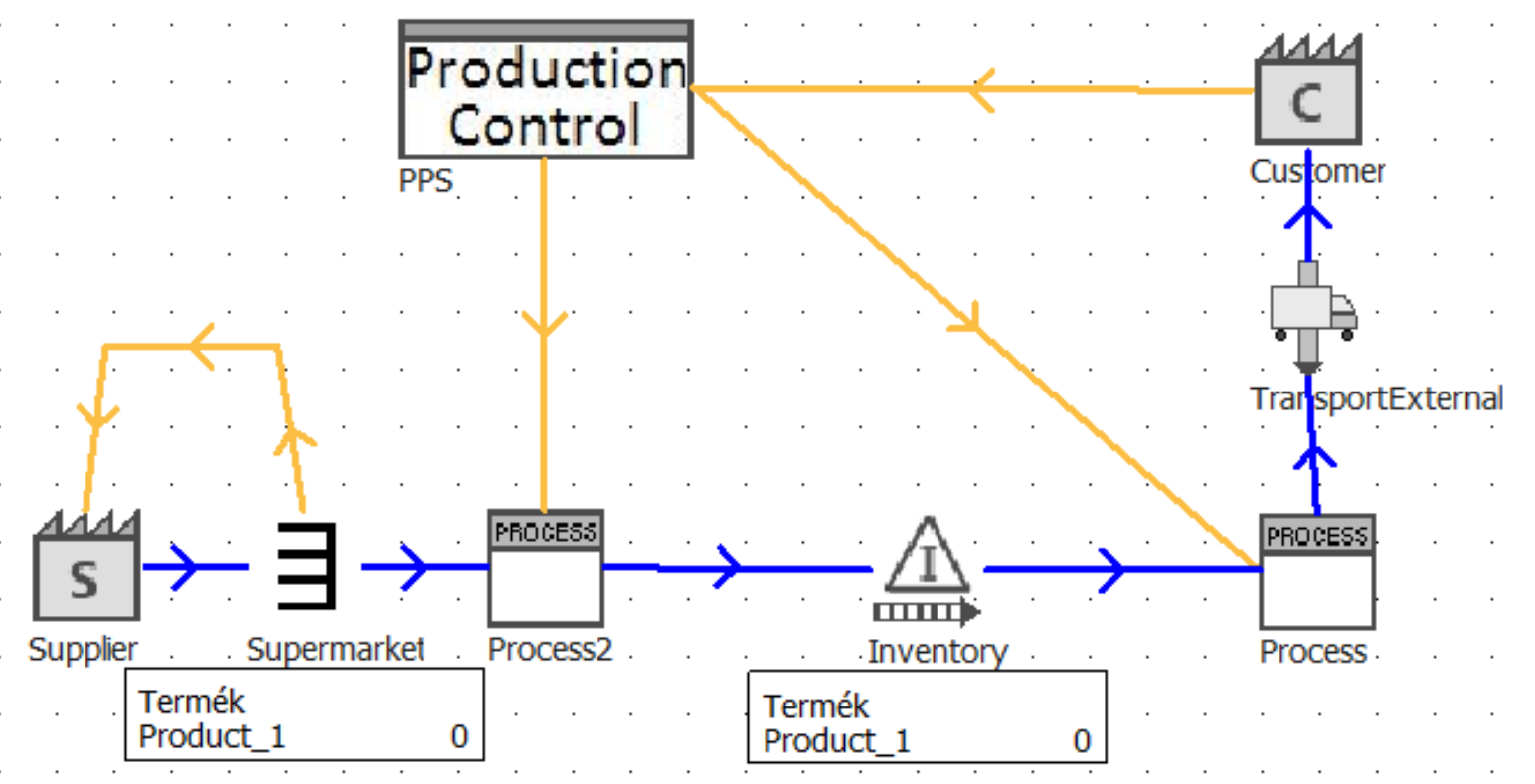

Fig. 2. Dynamic value stream map [Edited by me] 


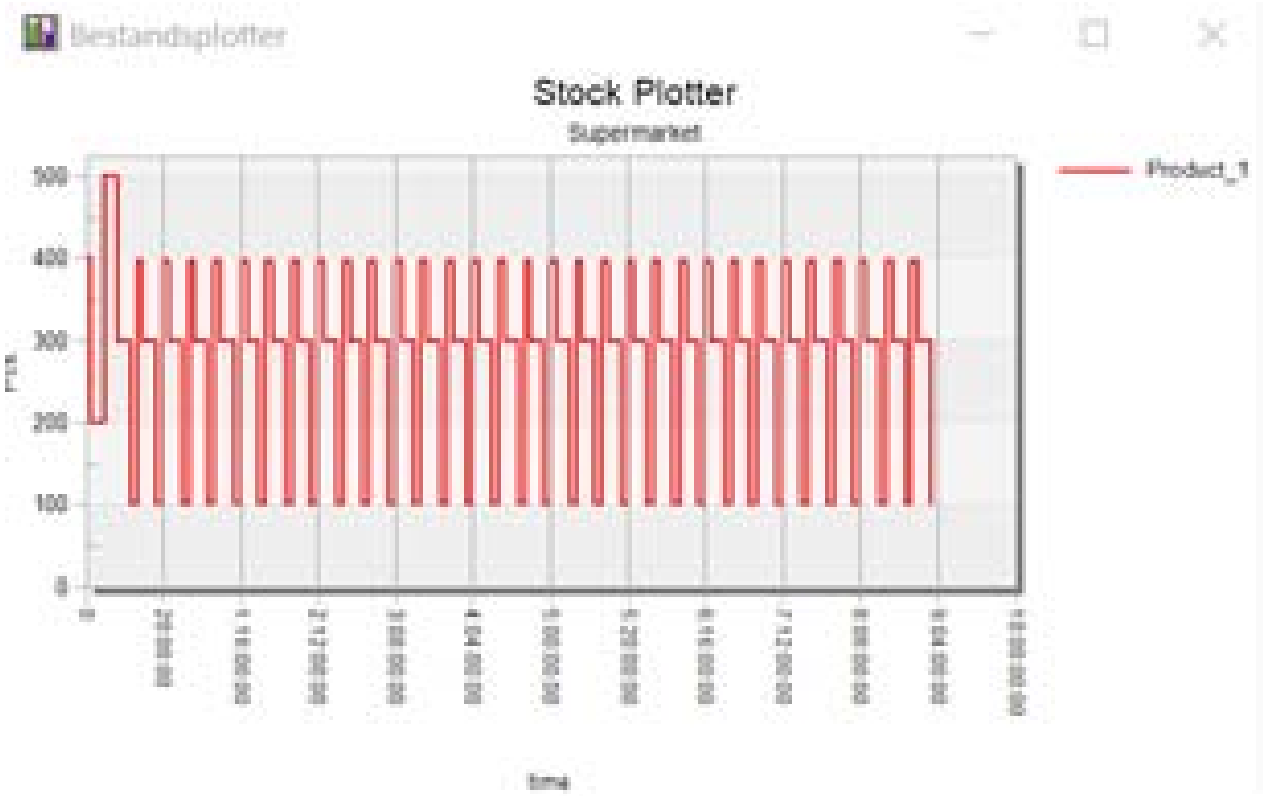

Fig. 3. Development of inter-operational inventory levels [Edited by me]

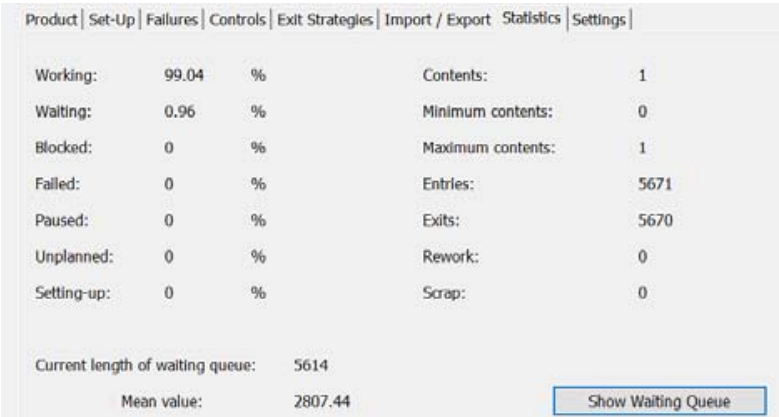

Fig. 4. Process-specific parameters

Overall, the method of dynamic value stream mapping will be one of the determining elements of process development due to the wide range of research possibilities [7-8].

\section{SUMMARY}

Due to the increasing complexity of logistics systems, it has become necessary to further develop the methods used so far in order to improve the processes efficiently. The paper examined a new type of value stream mapping method used for process development, namely the dynamic value stream mapping method. The benefits of using the method, the application process, and an example to illustrate the potential of the application are presented. It can be said that the static value stream mapping method used so far can only be used to develop the processes of one product family at a time using static data, while the dynamic version is able to examine the development possibilities of the subsystems. In my opinion, Digital Twinn technology, as well as the application of artificial intelligence, opens up new perspectives for the further development of the method.

\section{REFERENCES}

[1] Womack, J. P., Jones, D. T.: Lean thinking, Simon \& Schuster Inc., 2008.

[2] Rother, M., Shook, M., J.: Learning to See: Value Stream Mapping to Add Value and Eliminate Muda, Lean Enterprise Institute, 2003.

[3] Tamás, P.: Application of value stream mapping at flexible manufacturing systems, KEY ENGINEERING MATERIALS 686, 2016., pp. 168-173., ISSN: 1662-9795

[4] https://digitalisgyar.com/2015/07/15/ertekaramelemzes-plant-simulation-segitsegevel-1/ (retrieved: 2021.06.10.)

[5] Bányai, T., Bányainé T., Á., Illés, B., Tamás, P.: Ipar 4.0 és logisztika: Miskolc, 2019., ISBN: 978963-358-182-7, $160 \mathrm{p}$.

[6] Tamás, P.: Application of simulation modeling for formation of pull-principled production control system, JOURNAL OF PRODUCTION ENGINEERING 19: (1), 2016., pp. 99-102., ISSN: 1821-4932

[7] Cservenák, Ákos: Path and Trajectory Planning for an Automated Carrier Vehicle Equipped with two Conveyor Belts used in Manufacturing Supply, MANUFACTURING TECHNOLOGY 21:2, pp. 163-182. , 20 p. (2021)

[8] Borodavko, Beáta; Illés, Béla; Bányai, Ágota: Role of artifial intelligence in supply chain, ACADEMIC JOURNAL OF MANUFACTURING ENGINEERING 19: 1, pp. 75-79. , 5 p. (2021)

Authors: Péter Tamás, University of Miskolc, Faculty of Mechanical Engineering and Informatics, Institute of Logistics, Hungary, H-3515 Miskolc-Egyetemváros, Phone: (36) 46 565-111/17-39

E-mail: tamas.peter@uni-miskolc.hu 